\title{
Caractère Types and the Beaux - Arts Tradition: Interpreting Academic Typologies of Form and Decorum
}

\author{
By Diane Viegut Al Shihabi*
}

\begin{abstract}
The articulation of caractère types, or variations and qualities of architectural caractère, in Beaux-Arts interiors and how they transposed when translated in another culture are infrequently explored in design historical scholarship. Discerning the theories and doctrines of caractère types in French academic architecture will help illuminate the Académie's paramount objectives and also distinguish its intended meanings across cultures. This study asked (1) what historical and theoretical principles underlay the primary expressions of architectural caractère in the French Beaux-Arts tradition, and (2) how did caractère expressions manifest in Beaux-Arts interiors in France and abroad? It argues that the French Académie developed caractère types to communicate specific information about artistic history and contemporary society, in terms of tradition, purpose, and ingenuity. The paper's research methodology integrated literary analysis of period works, content analysis of architects' documents, material culture analysis of interiors, and iconographical analysis of symbolism. The study finds that preeminent caractère types in Beaux-Arts interiors, consistently reflected each room's purpose and its social importance through a classical and art historical form language that visually persisted when interpreted beyond France. Further, the connotations of visual social hierarchies varied over time and by location, and were individualized through discreet cultural semiotics, making the French architectural tradition germane to other sovereign states. The information is of value to academicians and practitioners, including historic preservationists and contemporary Neo Beaux-Arts classicists.
\end{abstract}

\section{Introduction}

Scarcely addressed in design history is the elocution of caractère types in Beaux-Arts interiors and how they were elucidated beyond France. The use of the word caractère as a quality of architecture and the word type as a metaphorical model developed within French architectural Académies. ${ }^{1}$ The etymologies of both terms lie in the Classical traditions of ancient Greece and Rome. The French word caractère equates to the Greek word characteer, a derivative of the verb charassein, which means to engrave or imprint with a

* Assistant Professor, Iowa State University, USA.

1. Germain Boffrand, Book of Architecture: Containing the General Principles of the Art and the Plans, Elevations, and Sections of Some of the Edifices Built in France and in Foreign Countries (1745), (ed.) Caroline van Eck, (trans.) David Britt (Burlington, VT: Ashgate, 2002); Antoine-Chrysostome Quatremère de Quincy, "Le Dictionnaire historique d'architecture (1832)," in The True, The Fictive and the Real: The Historical Dictionary of Architecture of Quatremère de Quincy (Part II), (trans.) Samir Younés. London: Andreas Papadakis, 1999, 59-270. 
distinctive sign or mark. ${ }^{2}$ Caractère evolved in architecture to express a small number of distinguishing or salient traits that proclaim the essence of an edifice to viewers and that remain etched in their minds. ${ }^{3}$ The French word type is a derivative of the Greek word typos, which in Classical sculpture referred to a visual form or model to be copied. In French architectural Académies, the meaning of type became more metaphorical than visual or physical, and referenced the idea of a paradigm to imitate, as opposed to a manifested model to copy. ${ }^{4}$ Type was a core idea, or a nucleus, as defined by the French academician Antoine-Chrysostome Quatremère de Quincy (Quatremère henceforth), that represented one rule, among many others, that an artist employed to create nuanced varieties. Interrelated to both concepts is the word style, derived from the Greek word stylos, an engraver's tool with a sharp point to trace characters on a sheet. The term evolved in French academic architectural theory from its literal meaning to designate a typical expression or countenance of a building and its elements. Quatremère defined style as the "distinctive physiognomy" belonging to each work of art, and to each author, genre, school, country, and/or century, that makes a general and understandable impression on the mind, and which differences in climate, materials, habits, mores, and the actions of governments and political or moral institutions may have an impact. ${ }^{5}$

The words Caractère, type, and style became integral axioms in the academic pedagogy of the French architectural tradition, particularly as it evolved within the École des Beaux-Arts during the late eighteenth and nineteenth centuries. ${ }^{6}$ Caractère visually asserted a building's essence, while embodying the ideas of style and type to manifest its preeminent qualities and variations. Remaining nebulous are how caractère types were expressed in interiors in the Beaux-Arts design system and how they transposed when translated in other cultures. Comprehending the Académie's theories and pedagogies that underlie architectural caractère types will illuminate the tradition's prominent objectives and also differentiate its intended meanings in France and beyond. This knowledge is particularly valuable for historic preservationists and contemporary practitioners, specializing in Neo BeauxArts Classicism.

2. Quatremère de Quincy, "Le Dictionnaire historique d'architecture (1832)," 103.

3. Ibid, 104.

4. Ibid, 254.

5. Ibid, 239.

6. Donald Drew Egbert, The Beaux-Arts Tradition in French Architecture, (ed.) David Van Zanten (Princeton, NJ: Princeton University Press, 1980), 125. 


\section{Research Questions and Methodology}

This study asks (1) What are the historical and theoretical principles underlying the primary expressions of architectural caractère in the French Beaux-Arts tradition, and (2) How did caractère types manifest within BeauxArts buildings in France and abroad?

The paper argues that the French Académie developed caractère types to disclose specific information about architectural history and contemporary society, in terms of tradition, purpose, and ingenuity. Further, that dictums guiding and uniting interior and exterior caractère types are not only essential components in the interpretation of the complex Beaux-Arts architectural tradition, but also in understanding its successful transposition and physical metamorphosis beyond France in the nineteenth and early twentieth centuries.

The paper's research methodology amalgamated literary analysis of period works, content analysis ${ }^{7}$ of architects' documents, material culture analysis ${ }^{8}$ of interiors, and iconographical analysis ${ }^{9}$ of symbolism. To decipher the key principles underlying French academic theories of caractère, the study examined how caractère variations developed, manifested in physical form, and acquired meanings over time. The study began by analyzing written discourse of classical and French academic architects to elucidate the foundation of caractère in Classical literature and in French academic architecture, and to interpret the caractère's assimilation over centuries in the French academic tradition. The study then evaluated how caractère qualities transposed when the French Beaux-Arts architectural approach was enacted abroad, drawing upon monumental American Beaux-Arts capitol buildings and their interiors. 10

\section{Literature Review}

This literature review traversed the development of architectural caractère in French academic architectural theory and identified caractère's relationship with the Beaux-Arts design approach. Inspired by Classical and Italian Renaissance precedents, French academicians viewed the Académie's architectural theory as encompassing three tiers: 1) metaphysical theory, the

7. Barbara Mostyn, "The Content Analysis of Qualitative Research Data: A Dynamic Approach," in The Research Interview: Uses and Approaches, (ed.) F. Brenner et al. London: Academic Press, 1985.

8. Jules David Prown, "Mind in Matter: An Introduction to Material Culture Theory and Method," Winterthur Portfolio 17, no. 1 1982): 1-19.

9. Erwin Panofsky, Meaning in the Visual Arts A59 (Garden City, NY: Doubleday Anchor Books, 1955).

10. This study analyzed exteriors and interiors of Wisconsin State (George Post, 19061917), Kentucky State Capitol (Frank Mills Andrews, 1909), and the Utah State Capitol (Richard Kletting, 1907-1916), and exteriors of Minnesota State Capitol (Cass Gilbert, 1905) and the Rhode Island State Capitol (McKim, Mead, and White, 1903). 
source of its conventions and rules, and quintessential meaning of its art, 2) didactic theory, the precepts and rules set forth in architects and academicians treatises and parallels, and 3) practical theory, the facts derived from physical examples. ${ }^{11}$ Metaphysical theory emanated from Plato and included the beliefs that there are physical and metaphysical realms, and that an ultimate measure of the good, the true, and the beautiful exists in the abstract realm. ${ }^{12}$ Didactic theory evolved from the analytical theories of successful architects of the past. It differed from practical theory in that it was reasoned and analyzed rather than manually acquired from physical activities. ${ }^{13}$ The French Académie's expressions and variations of caractère reflect theoretical underpinnings of each tier, yet only a few scholars have comprehensively analyzed caractère types in the French tradition to fully interpret the architects' intended messages.

Germain Boffrand introduced the terms caractère, style, and type into French academic architectural diction in Livre d'Architecture (Book of Architecture), published in 1745 in Paris, employing the concepts as modes of an intellectual language in architecture, as they were in literature. ${ }^{14}$ Boffrand was an influential member of the Royale Académie d'Architecture, established by Jean-Baptiste Colbert in 1671 under the auspices of Louis XIV, and was also an accomplished architect, best known for the interiors of the Hotel de Soubise (1709-1735). Over much of the eighteenth century, the terms genre, manner, or architectural order, continued to be used to describe the principal essences of architecture, rather than the words caractère or style.

Boffrand's student and a subsequent academician, Jacques-François Blondel, built upon his professor's work and expressed genres of tradition and purpose through variations of caractère and style. ${ }^{15}$ By the third quarter of the eighteenth century, he had incorporated both terms in academic instruction through Cours d'Architecture (1771-1776). ${ }^{16}$ While Boffrand and Blondel's scholarship provided insight into the French architectural tradition's development and applications of caractère, it did not include the perspectives or developments of the subsequent École des Beaux-Arts.

In the late eighteenth and early nineteenth centuries, Quatremère De Quincy, Secretary of the Académie des Beaux-Arts (1816 - 1839), became the first academician to comprehensively analyze caractère, style, and type from theoretical perspectives. He published analyses in Architecture, I (1788), 477521, in Encyclopedie Methodique (1825), and in abbreviated format in Dictionnaire historique d'architecture (Paris, 1832). In Dictionnaire, Quatremère identified three essential genres of caractère and associated the

11. Quatremère de Quincy, "Le Dictionnaire historique d'architecture (1832)," 247-248.

12. Samir Younés, "Quatremère de Quincy's Theory," in The True, The Fictive and the Real: The Historical Dictionary of Architecture de Quatremère de Quincy (Part I). London: Andreas Papadakis, 1999), 18.

13. Quatremère de Quincy, "Le Dictionnaire historique d'architecture (1832)," 249-250.

14. Guillaume Cavelier, Livre d'Architecture (Paris: 1745).

15. Caroline Van Eck, Book of Architecture, by Germain Boffrand (Burlington, VT: Ashgate Publishing, 2002), xxv.

16. Egbert, The Beaux-Arts Tradition in French Architecture, 110, 123. 
word style with historical traditions. His research was conducted first through paintings and literature, and then through architecture.

In the twentieth century, Donald Drew Egbert comprehensively analyzed caractère variations through winning drawings of the École's Grand Prix de Rome competition from the Académie's inception through 1968, and published findings in The Beaux-Arts Tradition in French Architecture (1980). Like Quatremère, Egbert identified three salient variations of caractère and analyzed their theoretical premises and prevalence in the French tradition.

Important to consider, Quatremère and Egbert examined the development of caractère and its qualities by drawing on Classical sources, the French Académie, and the École des Beaux-Arts. Quatremère died in 1849; hence, only Egbert's assessment could include the École's viewpoints and advancements from the second half of the nineteenth century. Also relevant, Egbert analyzed French competition drawings of monumental buildings of the Beaux-Arts tradition that were never built. He did not analyze realized buildings or their interiors in France or America. This leaves significant areas unexamined and gaps in scholarship to fully understand caractère manifestations in the BeauxArts tradition and their transposition abroad, which this study addresses.

\begin{abstract}
Analysis
Theoretical Principles Underlying Development of Primary Expressions of Architectural Caractère in the French Beaux-Arts Design System

To interpret French academic architecture's theories on caractère, type, and style, this study examined the classical traditions of ancient Greece and Rome, upon which the French tradition was built. French academicians identified the origin of architecture as nature, yet credited the Greeks with developing and perfecting the first rules of architecture, including the principles of proportion, fitness, commodity, safety, health, common sense, and so forth. They reasoned that the classical architects had copious opportunities to perfect rules of noble simplicity and harmony, through an extraordinary number of commissions for public edifices. ${ }^{17}$ Having recognized this, French academicians believed that it was the responsibility of the Académie to safeguard the established classical maxims and innovate within them. ${ }^{18}$

The French idea and meaning of architectural caractère relates to the classical notion of decorum, also translated as aptness or propriety. ${ }^{19}$ Quatremère described decorum as the appropriate manner to communicate good taste in all aspects of life (buildings, social etiquette, theatre, and so on). ${ }^{20}$ Knowledge of classical decorum in architecture came from extant buildings, archaeology, and literature, including the only architectural treatise to survive from antiquity, the Ten Books of Architecture by Roman author and architect
\end{abstract}

17. Boffrand, Book of Architecture, 6-7.

18. Ibid, 7.

19. Quatremère de Quincy, "Le Dictionnaire historique d'architecture (1832)," 214.

20. Ibid. 
Marcus Vitruvius Pollio (Vitruvius). Vitruvius defined decorum as that "perfection of style when a work is authoritatively constructed on approved principles," 21 of which proportion, or the relationship of parts to the whole to create unity, was the most important. ${ }^{22}$ Public and private buildings developed differently in classical architecture, with decorum of public temples designed to suit the rank and nature of a particular deity, and that of private domiciles designed to reflect the owner's social standing.

Vitruvius alluded to three qualities of decorum, which he termed prescription, usage, and nature. ${ }^{24}$ "Prescription" asserted a building's desired essence and was signified through a form, or forms, of an established tradition that over time became associated with the desired overall manifestation. Vitruvius exemplified his perception by citing the Doric order as appropriate for the temples of Mars and Hercules because its massiveness and solidity symbolizes the exceptional strength of these Gods (Figure 1). By contrast, the tall, slender, and noble Corinthian order was suitable to the temples of the delicate divinities such as Venus or Flora (Figure 2).

"Usage" signified a class of building relating to its purpose, and was depicted through a combination of forms established by tradition, with Vitruvius noting, "the usage in each class having been fixed long ago." 25 Vitruvius listed classes of public buildings by function, such as defensive, religious, and utilitarian. Public buildings were the most important structures for the Classical architects because they had to express the Empire's power and demarcate its authority. The decorum of usage required consistency between interior and exterior treatment. ${ }^{26}$

"Nature" referred to an expression of decorum arising from the particular location and peculiarities of the site. Available materials, building sites, and quality of natural light result in visible variations in character.

21. Marcus Vitruvius Pollio, Ten Books of Architecture, (trans.) Morris Morgan (New York: Dover, 1960), 14.

22. Ibid, 16.

23. Quatremère de Quincy, "Le Dictionnaire historique d'architecture (1832)," 70.

24. Pollio, Ten Books of Architecture, 14-15.

25. Ibid, 15.

26. Ibid. 


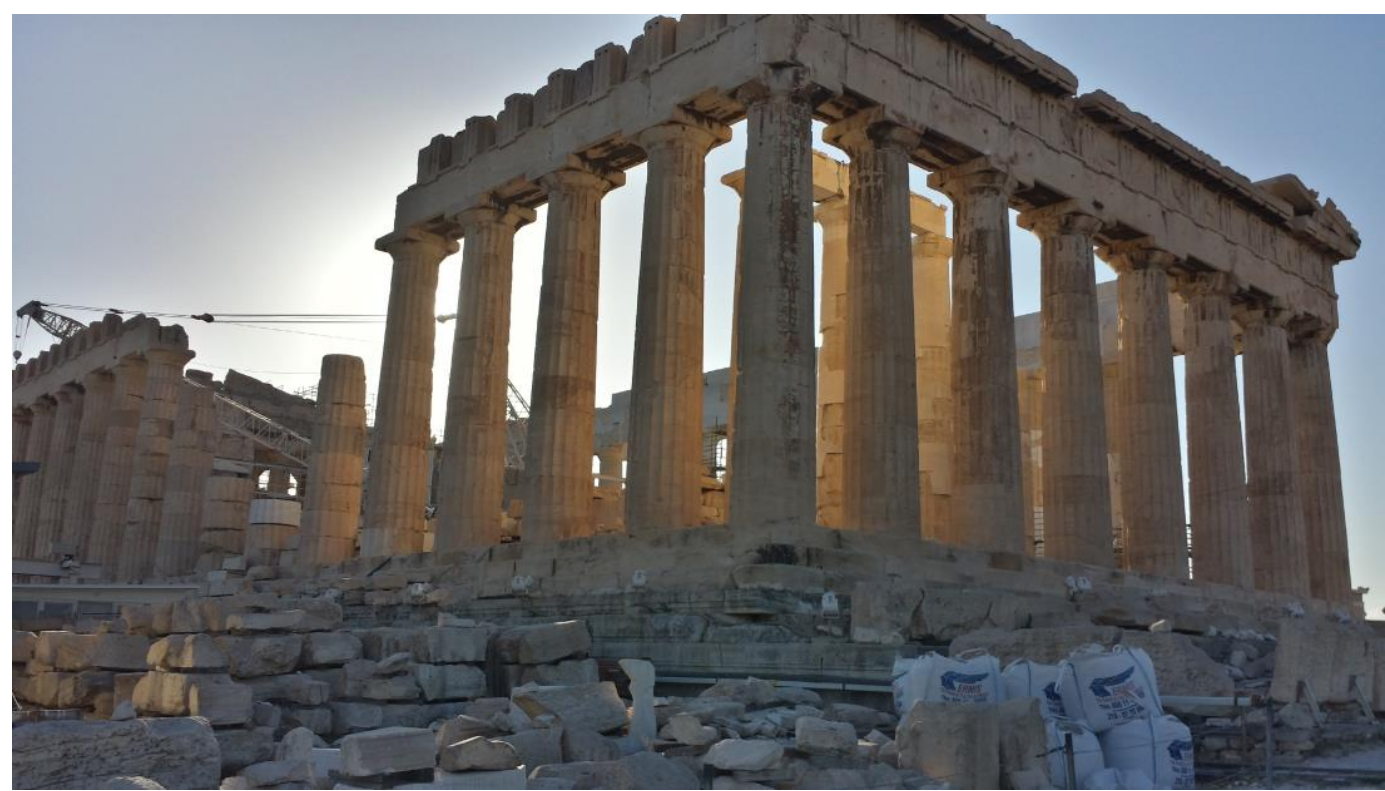

Figure 1. Doric Order, Parthenon in Athens, Greece

Source: Author.

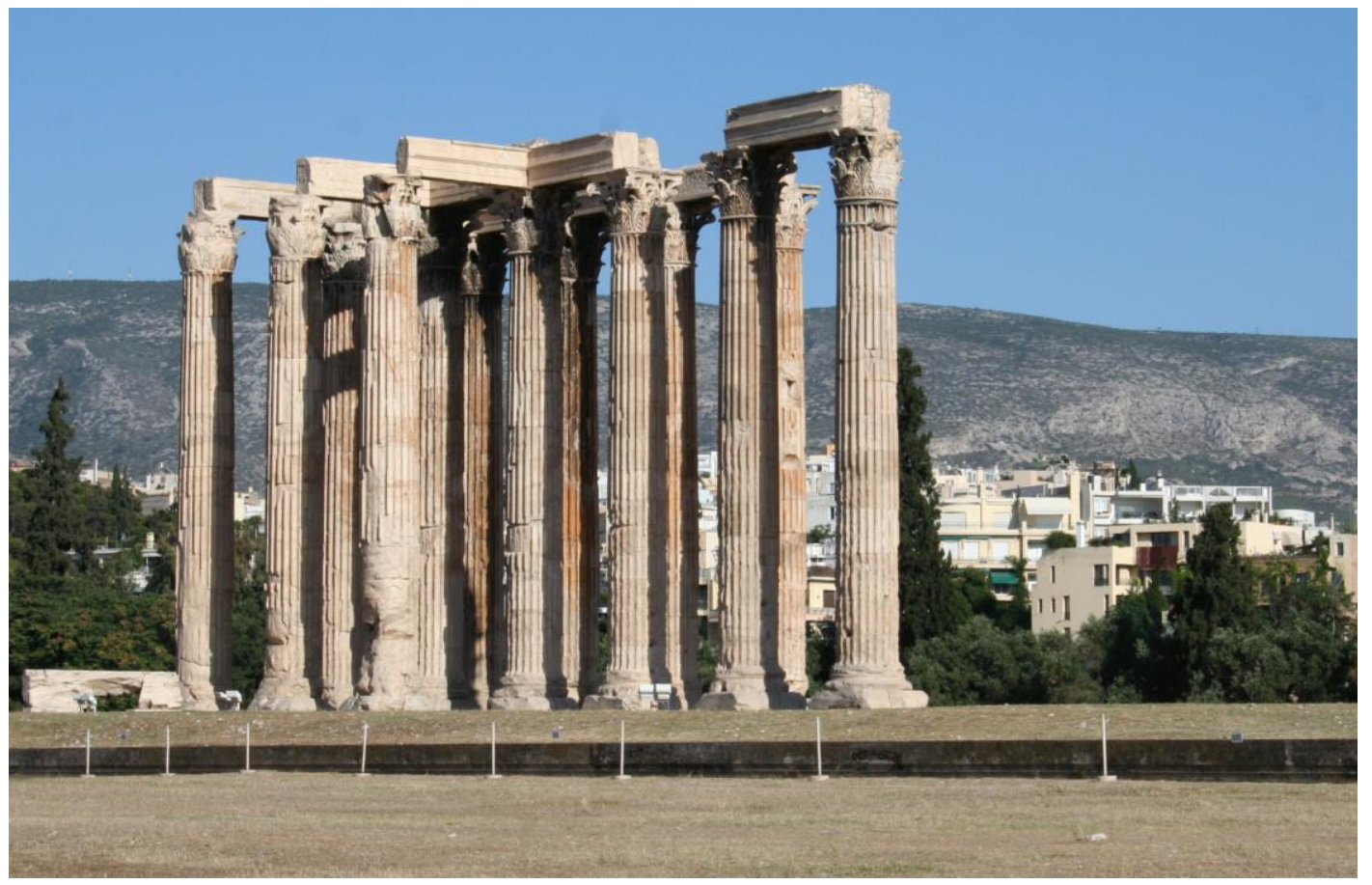

Figure 2. Corinthian Order, Temple of Olympian Zeus in Athens, Greece Source: Author.

Correct application of decorum required architects to have a wide knowledge of history to achieve excellence, in part because the ornamental parts of a building have underlying ideas, or connotations, that the architect should be able to explain to inquirers. ${ }^{27}$ Vitruvius exemplified this requisite

27. Ibid, 6. 
through Caryatids, the symbols of the eternal enslavement of women from Caryae, a Peloponnesus state that sided with the Persian enemies against Greece (Figure 3).

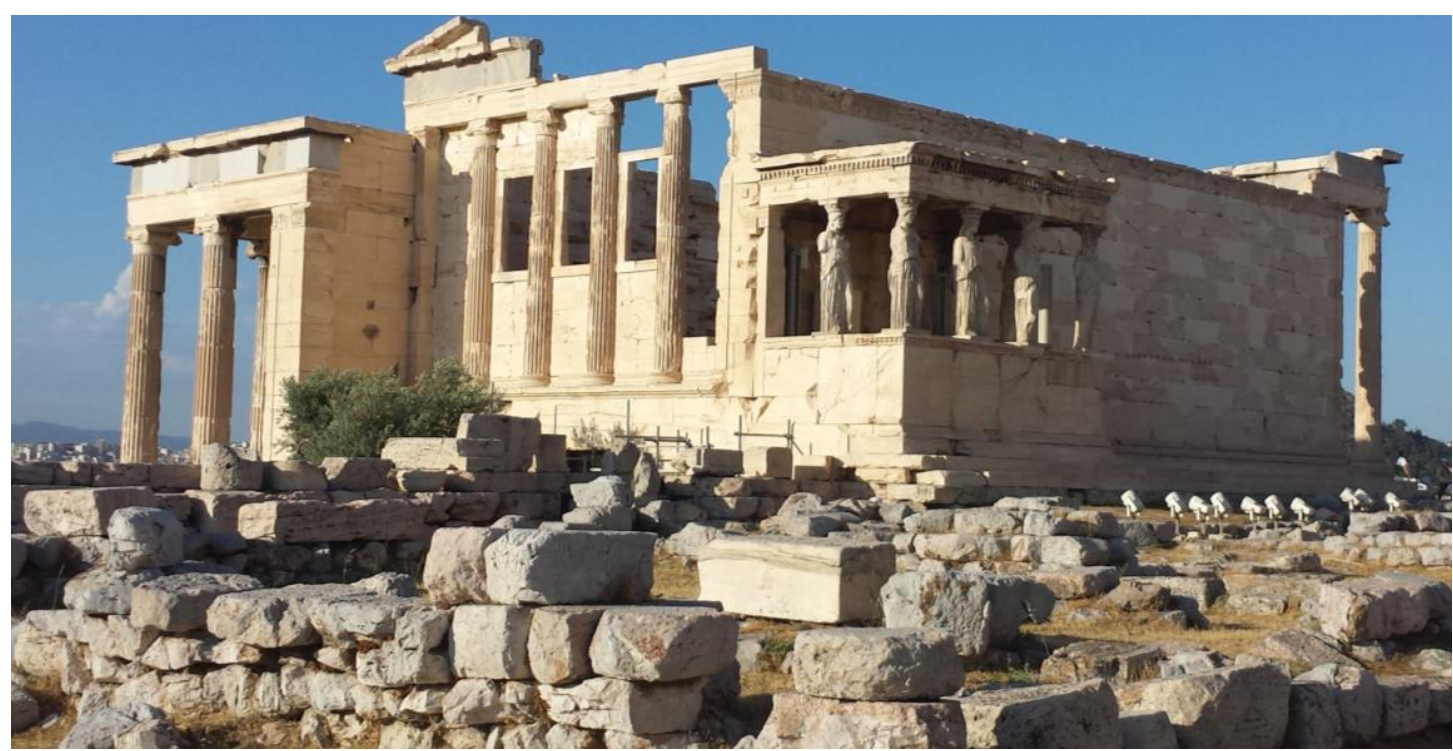

Figure 3. Caryatids, Erechtheion, Athens, Greece Source: Author.

Collectively, variations in the classical notion of architectural decorum relate to ideas of a building's essence, purpose, and site. A hierarchy of status, rooted in metaphysics, and conventions of design thought to yield beauty and good taste mediated these qualities.

The classical doctrine of decorum persisted in French architectural Académies, but the concept was associated with the word caractère in the eighteenth century. Boffrand's 1745 treatise, Livre d'Architecture, was the first to assimilate the terms caractère, style, and type into architectural diction and theory. The treatise was based on the academician's analysis of lexica in classical rhetoric, and in particular, that of Roman poet Quintus Horatius Flaccus' (commonly known as Horace) and his writings in the Art of Poetry. Boffrand believed that a close affinity existed between poetry, sculpture, painting, and architecture, such that the principles of one are also the principles of the other, which in turn allowed the language of each to be interchanged. ${ }^{28}$ In Livre and through the classical precepts of Horace and Vitruvius, Boffrand formed analogies between architecture and poetry as exemplified below:

Horace: If I cannot observe the requirements of each genre, and the colouring proper to every style, why should I be called a poet?

Boffrand: A man who does not know these different caractères, and who does not make them felt in his work is no architect. ${ }^{29}$

Boffrand rationalized that just as poetry has its various genres and styles; architecture is capable of different genres and caractères to allude to a

28. Boffrand, Book of Architecture, 8.

29. Ibid, 10 . 
building's overall essence and hierarchical purpose. He wrote, "As the genres of poetry are to its chosen subjects, so are the orders of architecture used by the Greeks and Romans to the various genres of building. ...These orders of architecture, with their progression from the rustic to the sublime, have proportions relative to their caractère and to the impression that they are intended to make." $" 30$

Boffrand stressed that different functional purposes were to be declared through different architectural elements, writing, "By their planning, their structure and their decoration, all buildings must proclaim their purpose to the beholder." Every decorative part was to relate to the whole through forms appropriate to use and to the rules of proportion.

Boffrand, like Vitruvius, recognized the need for flexibility and individuality within established doctrine, noting, "What is right for one nation is not right for another. All have their different ideas of beauty.... Every country in the world has its own dominant caractère." 31 Further, Boffrand noted that architects add their own caractère, and must constantly study people and conditions in their own time. ${ }^{32}$ This rationale facilitated a level of flexibility, variation, and individual expression within the French academic tradition.

As in classical architecture, a social hierarchy of architecture endured in the French Académie, but it was used to exalt a mortal King rather than metaphysical deities. With the progression of the eighteenth century, the French society became more open and the hierarchy of buildings expanded to encompass not only royal edifices, but also other public buildings. ${ }^{33}$

Adhering to the classical tradition, French academic canons of design were applied to facades of public temples and palaces, and also to those of private houses and interiors. Boffrand considered interior decoration an important part of architecture and included a chapter on interiors in Livre. Just as building facades must express social rank, the academician called for a hierarchy of interior rooms, corresponding to the social rank of the occupants, and noted that interior decoration and furniture must be developed "with a view to their uses and to the just grades of distinction between rooms occupied by servants and by the master." 34 Architects were to design in accordance with the client's social rank and preferences, and to ensure that proportions unified the overall expressions.

All interior elements - ceilings, plasterwork, suites, furnishings, and so forth- were to vary to suit a room's use, be consistent in grandeur to other ornament, be in proportion to the room, and increase in beauty from room to room as the social hierarchy progressed. Large salons and galleries required different kinds of ornaments, yet they were to be holistically conceived, as

\author{
30. Ibid. \\ 31. Ibid, 6. \\ 32. Ibid, 10 . \\ 33. Egbert, Beaux-Arts Tradition in French Architecture, 141. \\ 34. Boffrand, Book of Architecture, 6.
}


described by Boffrand, "In general, every department of architecture, sculpture, and painting must combine to make a single whole., 35

To summate, through Livre Boffrand formed analogies between architectural aesthetics and classical poetry to explicate universal principles of taste and beauty in the arts. ${ }^{36} \mathrm{He}$ used reason and analysis to help frame primary theorems underlying architectural caractère (exterior and interior), and to illustrate their meanings and relationship to the building's purpose and overall hierarchical organization.

In the third quarter of the eighteenth century, Boffrand's student and subsequent academician, Jacques-François Blondel, built upon his mentor's theories in Cours d'Architecture (1771-1777), adding to academic instruction his interpretation of style and its relationship to caractère. Through form and ornament, style in Blondel's sense, could denote a building's essence, or caractère, and could unify the building. He explained, "By style in Architecture is meant the true genre, which one must choose with respect to the motive, which led to the construction of the building....Style can equally well paint the sacred genre, the heroic, and the pastoral genre; Style can express in particular the caractère." 37

Refining and further articulating Boffrand and Blondel's conceptions of style, in the late eighteenth and early nineteenth centuries, Quatremère, Secretary of the Académie des Beaux-Arts, defined style as a "characteristic or typical form" and as a means to identify and classify historical traditions, a theoretical construct that he also equated to a predominant quality of caractère. "Style, as we say, becomes synonymous with caractère, or with the individual manner of the distinctive physiognomy, which belongs to each work of art, each genre, each school, each country, each period."38

Quatremère, like Boffrand, viewed architecture as an artistic language, with caractère, types, and styles as its diction, writing, "Architectural legibility depends on congruence between type, caractère and style." " Quatremère limited the essential qualities of caractère to a small number of "supereminent distinctions" that endowed a building with its primary importance, rather than innumerable levels and varieties of elements. ${ }^{40}$ Specifically, he identified three different expressions of architectural caractère, and termed the variations essential, relative, and distinctive, relating to tradition, purpose, and originality, respectively. ${ }^{41}$

"Essential caractère," to Quatremère, is something unique belonging to a remote age, "an emphatic expression of the needs and taste of a nation in its youth," with a simplicity and harmony that could only be considered as a historical theory. It is a peculiar quality arising from a small number of central

35. Ibid, 17.

36. Van Eck, Book of Architecture, xi, xiv.

37. Jacques-François Blondel, "Cours d'architecture," in Book of Architecture by

Caroline van Eck. Burlington, VT: Ashgate, 2002, xxv.

38. Quatremère de Quincy, "Le Dictionnaire historique d'architecture (1832)," 238.

39. Younés, "Quatremère de Quincy's Theory," 41.

40. Quatremère de Quincy, "Le Dictionnaire historique d'architecture (1832)," 104.

41. Egbert, Beaux-Arts Tradition in French Architecture, 136. 
ideas and is expressed with the principles of unity and simplicity. He writes, "Such monuments must be the product of some great affection that embraces the entirety of a country's inhabitants, and that concentrates on some vast subject of common admiration." façades, and in traditional forms that connote grandeur, force, power, or other desired qualities to convey the building's essence or principal effects. ${ }^{43}$ Quatremère's notion of essential caractère is a successor to Vitruvius' idea of prescription.

"Relative caractère" reflects the appropriate nature to profess a building's purpose or "its caractère." According to Quatremère, it is the notion of caractère most often is designated in architectural theory, because academic instruction can influence it, whereas the first and last varieties depend on the causes, believed at the time, to be largely beyond the academician's reach. ${ }^{44}$ Quatremère's idea of relative caractère is a derivative of Vitruvius' term usage.

"Distinctive caractère" arises from originality and is inferred when one says a building has "a caractère." It is an individual imprint and a quality that is original and not copied or borrowed, but rather inspired by the confidence of genius and has an ability to create independently from conventions after observance and study that no didactic teaching can propagate. ${ }^{45}$ Quatramère's interpretation of distinctive caractère is similar to Vitruvius' sense of nature, since both terms reflect ingenuity in design.

Since "relative caractère" could be taught and because Quatremère considered the knowledge to produce it among the most valuable skills that a designer could possess, he elaborated upon it in his writings. In his words, "The art of characterizing each building, that is to say, of rendering evident through material forms, and explaining the qualities and properties inherent to its purpose, is perhaps of all the secrets of architecture the most valuable to possess and at the same time the least easy to predict." was to comprehend the ideas that corresponded to a monument's purpose and the artistic language needed to signify it through three principal means, 1) forms of the plan and elevation, 2) selection, scale, and application of ornament and decoration, and, 3) architectural massing, and kinds of construction and materials. $^{47}$

Quatremère notes that it is from the plan that the elevation results, so it is essential that designers considered the plan with intelligence and in anticipation of the building's purpose. Customary use facilitated some uniformity in plans for the various genres of buildings; however, architects developed individual plans to address each building's requirements.

\footnotetext{
42. Quatremère de Quincy, "Le Dictionnaire historique d'architecture (1832)," 105.

43. Ibid, 104.

44. Ibid, 106.

45. Ibid.

46. Ibid, 107.

47. Ibid.
} 
An intrinsic means to impart relative caractère was decoration, which encompassed exterior and interior sculptural ornament and interior painting, among other finishes. Decoration was the designer's intelligible and communicative language that engaged the intended viewer's intellect, emotions, and imagination to understand signs, using variety, diversity, contrasts, history, allegories, and other semiotics just as history and poetry had done. Quatremère considered allegorical and historical figures principal communicative devices in architectural decoration to engage perception, passion, and inspiration. ${ }^{48}$

Determining the appropriate expression of relative caractère for each genre of building, and then prescribing it through available decorative resources required the discernment between forms and ornaments, and knowledge of how to apply both with economy and harmony. Relative caractère was strengthened through the genre of construction and the nature of materials. Quatremère cites marble as having a particular effect on a large number of viewers, adding that the dimension and volume of stones have the ability to connote ideas of strength, gravity, richness, delicacy, delight and elegance. In addition the quality, rarity, color, variegation, and combination of stones could strengthen the impression of relative caractère, because an "instinct for variety" is common to all peoples and is found in all works of art.

Quatremère and other academicians recognized that some architects rejected ornament reasoning that "real beauty needs no adornment," or that the "absence of ornaments can be seen as decoration." 49 The foremost view in the Académie, however, was that while architecture could manifest the greatest beauty in the most common material, ornaments has the ability to "grant the senses that they rightly demand" just as painting does through the vivacity of contrast in hues and the variety of tones. ${ }^{50}$ When necessary, decoration's role in architecture was to state a monument's core idea (purpose) to spectators and stimulate their sensorial response to it. ${ }^{51}$

To Quatremère, embodied within the concept of caractère is the idea of "type." Quatremère defined type as "less the image of a thing to copy or imitate completely, than the idea of an element, which must itself serve as a rule for the model. ${ }^{, 52}$ In architecture, a type is a form or combination of forms from which a designer can create varied individual manifestations. The idea of type is of a pre-existing seed, antecedent, origin, primitive cause, or core convention that a viewer's mind can recognize, even when a designer manipulates it. Quatremère calls type, an "elementary principle...like a sort of nucleus around which are assembled...all the developments and the variations of form to which the object was susceptible., 53 Type is identifiable through history, in literature and realized monuments, and is perpetuated by a

\footnotetext{
48. Ibid, 135.

49. Ibid, 111 and 132.

50. Ibid, 111.

51. Ibid, 132.

52. Ibid, 254-255.

53. Ibid.
} 
civilization's customs, taste, and use. The idea is broadly engaged in architecture and interiors, referencing building type, furniture type, decorative painting type, sculpture type, and so forth.

Donald Egbert associated the word 'type' with a particular expression of caractère in the twentieth century. Egbert analyzed caractère variations through winning programs of the French Académie's annual Grand Prix de Rome competition, via archival records of the École des Beaux-Arts in Paris. In the Beaux-Arts Tradition in French Architecture (1980), Egbert identified three distinct variations of architectural caractère, which he termed general, type, and specific. ${ }^{54}$ General caractère related to the building's level of importance and overall style; it was independent of the architectural purpose of the building, and was conveyed by traditionally accepted forms (Doric order for strength, Corinthian order for nobility, and so on), traditionally accepted styles (Italian Renaissance, French Baroque, and others), and durable materials that had become associated with public buildings (marbles and other fine or rare materials). ${ }^{55} \mathrm{By}$ the nineteenth century, different styles reflected the École's erudite taxonomy of building traditions.

Type caractère elucidated a building's function through a specific configuration of forms that had come to be associated with a particular use (museum, library, theater and so on). It also reflected the nineteenth century's expanding typology of buildings. Egbert's sentiment of type caractère arose from Quatremère's idea of relative caractère and Vitruvius' view of usage.

Specific caractère related to individual variations arising from requirements of the site, use, materials, and construction methods, and from the innate genius of the architect. Egbert associated this variation in the French Beaux-Arts tradition with early twentieth century modern movements in architecture, which were present, but not prevalent in the Académie. He noted that the emphasis on functionalism in Corbusier's work, among others, reflects a specific caractère. Egbert further delineated 'architecture parlante,' an architectural expression that lies between specific and type caractère. ${ }^{56}$ It is evident in unique buildings that have no association with pre-existing examples or types, and is exemplified by the work of Claude Ledoux. Important to this study, Egbert argued that general and type caractère were essential to express in typical Beaux-Arts designs from the mid-nineteenth century through $1968 .{ }^{57}$ Also significant, to define general caractère or a building's overall and inimitable essence, Egbert coalesced notions of styles, materials, and proportions. Differing from Quatremère, Egbert implies that as the Beaux-Arts tradition developed, general and type caractère could be taught.

In the Beaux-Arts Tradition in French Architecture, Egbert argued that since the seventeenth century French academic architects ranked buildings in a Neoplatonic hierarchical organization based on social purpose, with designs ranging from utilitarian to monumental. They also depicted architectural

54. Egbert, Beaux-Arts Tradition in French Architecture, 122-123.

55. Ibid.

56. Ibid.

57. Ibid, 125, 134. 
caractère through prescribed forms and styles, consistent with Aristotelian philosophy. Utilitarian buildings possessed practical values and expressed lower social importance in simple modern forms and styles, and common materials. By contrast, monumental buildings possessed universal and permanent values and expressed their greater importance through the noblest forms and styles, and also the noblest and most durable materials. French academic architects considered Italian and French Renaissance and Baroque styles of the seventeenth and eighteenth centuries the most noble and suitable for monumental buildings and high-ranking interiors.

To cipher cardinal points, Boffrand introduced the terms caractère, style, and type into the Académie's architectural theory, while his student Jacques François Blondel incorporated the terms into academic instruction. Vitruvius, Quatremère, and Egbert used varying terms to identify and define preeminent caractère variations or qualities, yet the meanings of their words consistently related to traditions, use, and ingenuity and varied by culture, location, and architect. Architects of the French classical tradition conscientiously expressed a limited number of caractère variations in a hierarchical ordering arrangement, based on the social importance and purpose of each building. Every part of a building's exterior and interior was to be united through appropriate forms, principles of architecture, and grades of distinction. In the École, variations of architectural caractère became stylistic and typological constructs to guide artistic expression of a building's desired essence and the purpose or purposes. A Neoplatonic social hierarchy of building types and interior programs further mediated the expression of caractère.

As elucidated by Boffrand and Quatremère, the Académie recognized that countries have their own ideas of beauty and caractère, and anticipated variety and individual expression among different nations. The following section examines how caractère types and social hierarchies manifested in monumental Beaux-Arts buildings and their interiors beyond France.

\section{Transposition and Interpretation of Caractère in American Beaux-Arts Architecture}

To understand the translation of French academic architectural caractère beyond France, this study analyzed the facades and interiors of the Wisconsin State Capitol, designed by George Post (1906-1917), the Kentucky State Capitol, designed by Frank Mills Andrews (1909), and the Utah State Capitol, designed by Richard Kletting, (1907-1916). It also examined the exteriors of Minnesota State Capitol, designed by Cass Gilbert (1905), and the Rhode Island State Capitol, designed by McKim, Mead, and White (1903).

According to Quatremère, Beaux-Arts training taught designers to comprehend ideas that corresponded to a monument's purpose and to determine the artistic language that was needed to signify it through plans, elevations, ornament, and massing. The purpose of American Beaux-Arts capitols, as noted by George B. Post, New York architect of the Wisconsin capitol, was to visually communicate the power of the government through an 
artistic and technological language that could educate the public and be understood as good taste in the present and in the future:

It is the proud boast of the architect that his work forms the most positive and enduring evidence of civilization....In all countries and times, the Government has been the great builder. Is the American architect so far behind the world in professional skill that our public buildings must of necessity be bad in design, vulgar in detail and extravagant in construction $?^{58}$

In the same speech, Post lauded the government buildings of ancient Egypt, Greece, and Rome and those of modern Europe as exceptional examples. During the construction of the Wisconsin State Capitol, Post expounded further that he sought a monumental caractère, consistent with the theoretical principles of the French Acadèmie and classical Greece:

Stimulated by the belief that we were erecting an architectural monument in the Wisconsin State Capitol, which would be a model for buildings of its class, and which would as such exert a great educational influence throughout the land....We are confident that a result has been achieved which in its simplicity and grandeur combined with dignity and harmony of proportion and color may safely challenge comparison with anything of the character in the country. ${ }^{59}$

From the perspective of a Beaux-Arts architect, monumental caractère would call for the most revered academic styles, either Italian Renaissance or French Baroque, a stone façade, and a grand scale that visually acclaimed strength and power. The building's governmental purpose would require a combination of forms, or a type of caractère that had come to be associated with such buildings. Prior American capitols followed the Italian Renaissance temple architecture. The configuration of forms included a central mass with a high dome, wings, and an attic story, a concept derived in part from St. Peters and Michelangelo's high dome (completed in 1590), among other buildings. All five American Beaux-Arts capitols examined exhibit this configuration, demonstrating consistent expressions of general and type caractère. ${ }^{60}$ To impart interior caractère types, American Beaux-Arts architects required an understanding of each room's purpose in a democratic infrastructure in order to rank them from the most practical and utilitarian to the most ceremonial. Once ranked according to social importance, architects could develop interior caractère types through different styles, configurations of forms, and graduated levels of finishes. Since American Beaux-Arts architects also sought to create an American art form, they contemplated how to amalgamate American symbolism within the French academic framework.

58. George B. Post, Architects at Dinner (New York Times, February 14, 1895).

59. George B. Post to Geo. H. D. Johnson, Series 833 Correspondence (Madison: Wisconsin Capitol Commission Files, Wisconsin Historical Society, 1909).

60. Cass Gilbert Collection (PR 21) (New York: New York Historical Society, 18791934); George B. Post and Sons Architectural Records Collection (New York: New York Historical Society Library); McKim Mead and White Architectural Records Collection (New York: Historical Society Library); Kentucky State Capitol Papers (Frankfort, KY: Division of Historic Properties); Utah Capitol Commission Files (Salt Lake City: Utah State Archives). 
The rotundas and main corridors of the Beaux-Arts capitols reflect the highest level of social importance from the French academic perspective, which prioritized public functions, and the highest ideals of a democratic government from the American perspective, which prioritized the voice of the people. These spaces rank at the top of the Neoplatonic hierarchy of interior rooms and spaces, and required expressions of general and type caractère consistent with their monumental and ceremonial importance.

In the Wisconsin State Capitol, Post signified the rotunda's paramount status through Italian Renaissance styles and forms, colossally scaled columns, walls and floors sheathed in noble stone, costly gilded ornament, sophisticated complementary colors schemes, and other means. American materials, remarkable American artwork, and innovative American technology exalted the rotunda's stature as an American art form. Pilasters encircling the rotunda are sheathed in Wisconsin Montello granite, while piers supporting the first floor are sheathed in imported Norwegian Labradorite. Pendentives display colossal and spectacular foil-backed glass mosaics designed by Kenyon Cox, an American artist and graduate of the École des Beaux-Arts (Figure 4).

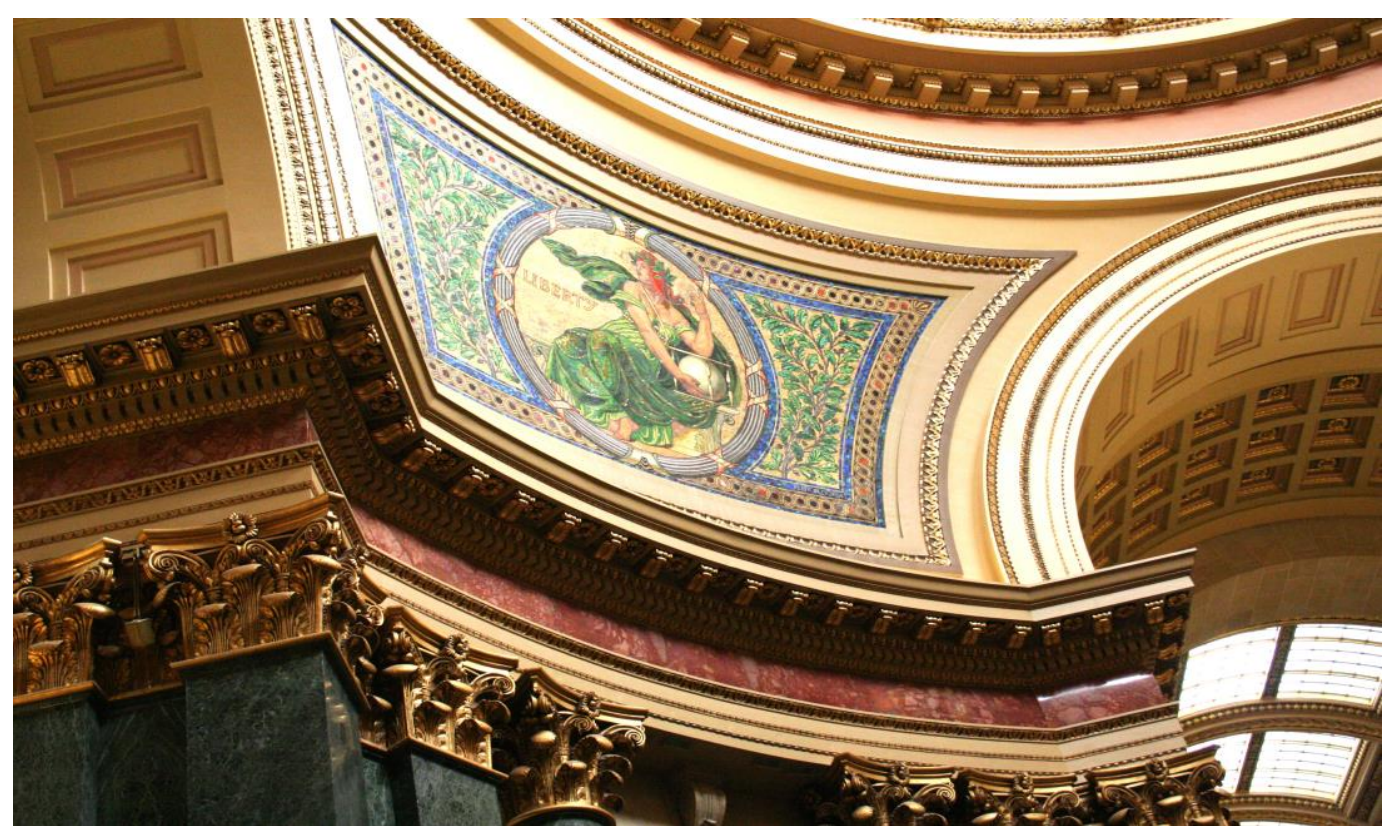

Figure 4. Wisconsin State Capitol First Floor Rotunda, Mosaic by Kenyon Cox, 1917

Source: Author.

Post impressed visitors by incorporating the latest American technology in the form of indirect electric lights, concealed behind cornices in the rotunda's dome to illuminate the oculus mural. The architect further delineated monumental caractère by the complexity of construction and rarity of materials; hence, the rotunda has the most elaborately patterned marble floor in the building and the rarest imported stones. Walls of main corridors are fully sheathed in stone, while minor corridors are plastered, painted, and trimmed in wood. 
Comparatively, the rotunda and main hall of the Kentucky state capitol convey monumental caractère through a massive central hall that exhibits colossal columns, fenestrated barrel vaults, and a marble grand staircases ascending to the first, second, and third floor levels (Figure 5).

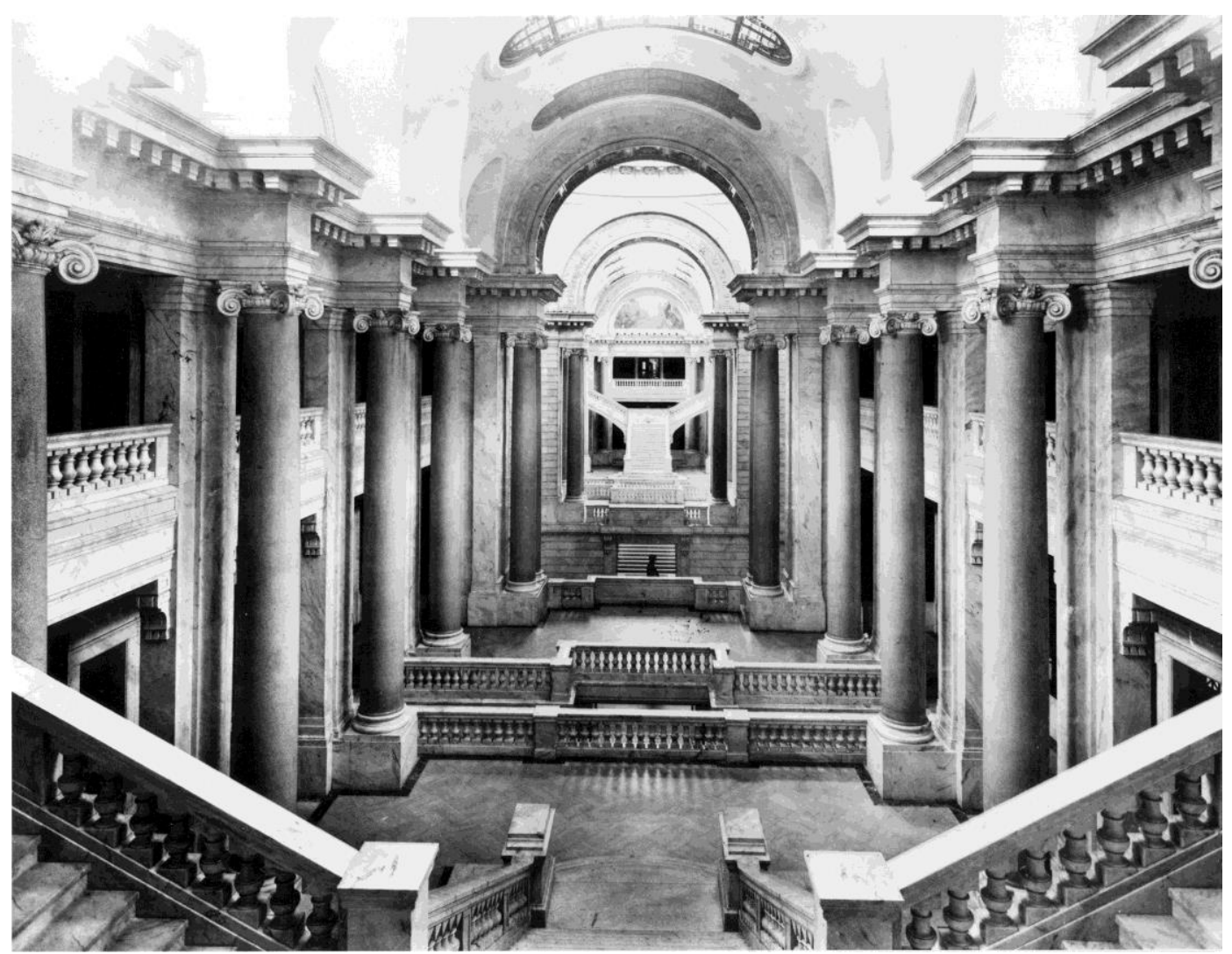

Figure 5. Interior Main Hall, Kentucky State Capitol, ca. 1910

Source: Photo Courtesy of University of Kentucky Archives.

Landings exhibit lunette paintings by T. Gilbert White (1909) that memorialize Kentucky's history. Other fine art also commemorates the state's heritage, including, "Boone and Companions taking their First View of the Kentucky Valley," an oil painting that adorns the East Wing. The Kentucky capitol influenced by the design of the centric axial hall of the Utah State Capitol, similarly lit through fenestrated barrel vaults and lined with two-story monolithic Ionic columns, fabricated in Georgian marble. Lunette murals commemorate Utah's history. The hierarchy of interior offices and rooms present on Post's drawings, to which other capitols similarly corresponded, ${ }^{61}$ includes ten categories: Clerks and Business Offices (lowest); Secretaries to Department Chiefs/Committee Rooms; Department Chiefs; Executive Secretary, Governor/Attorney General Reception Offices/Supreme Court

61. George B. Post and Sons Architectural Records Collection (New York: New York Historical Society Library); Wisconsin Historical Images Collection (Madison: Wisconsin Historical Society); Kentucky State Capitol Papers (Frankfort: Division of Historic Properties); Utah Capitol Commission Files (Salt Lake City: Utah State Archives). 
Consultation Room; Governor's Private Office; Law Library Reading Room; Senate and Assembly Parlors; Executive Chamber, (highest); Supreme Court Chamber (highest); and Senate and Assembly Chambers (highest). The first four and lowest ranked categories pertained to semi-private and private staff offices, while the remaining categories pertained to rooms with increasing levels of public functions and ceremonial importance. Post asserted variations of type and general caractére in the lowest categories through combinations of modern forms and styles, common materials, and simple construction methods. The architect expressed types of caractere in the remaining six categories through configurations of historic forms that had come to be associated with different public room types in the French academic tradition, including Library Reading Rooms, Reception Rooms, and European Council Chambers. General caractére was indicated through historic forms and styles, rare and imported materials, and increasingly complex construction. The room category 'Clerks and Business Offices,' represented the lowest level of democratic function in the Wisconsin State Capitol and the lowest expression of caractere types in the capitol's interiors. While rooms in this category were found on all floors in the Wisconsin State Capitol, they were most prevalent on the ground and attic floors (third and fourth). Modern reform styles, and particularly those of the Arts and Crafts Movement, communicated general caractére through simplicity in pattern, ornament, and form (Figure 6).

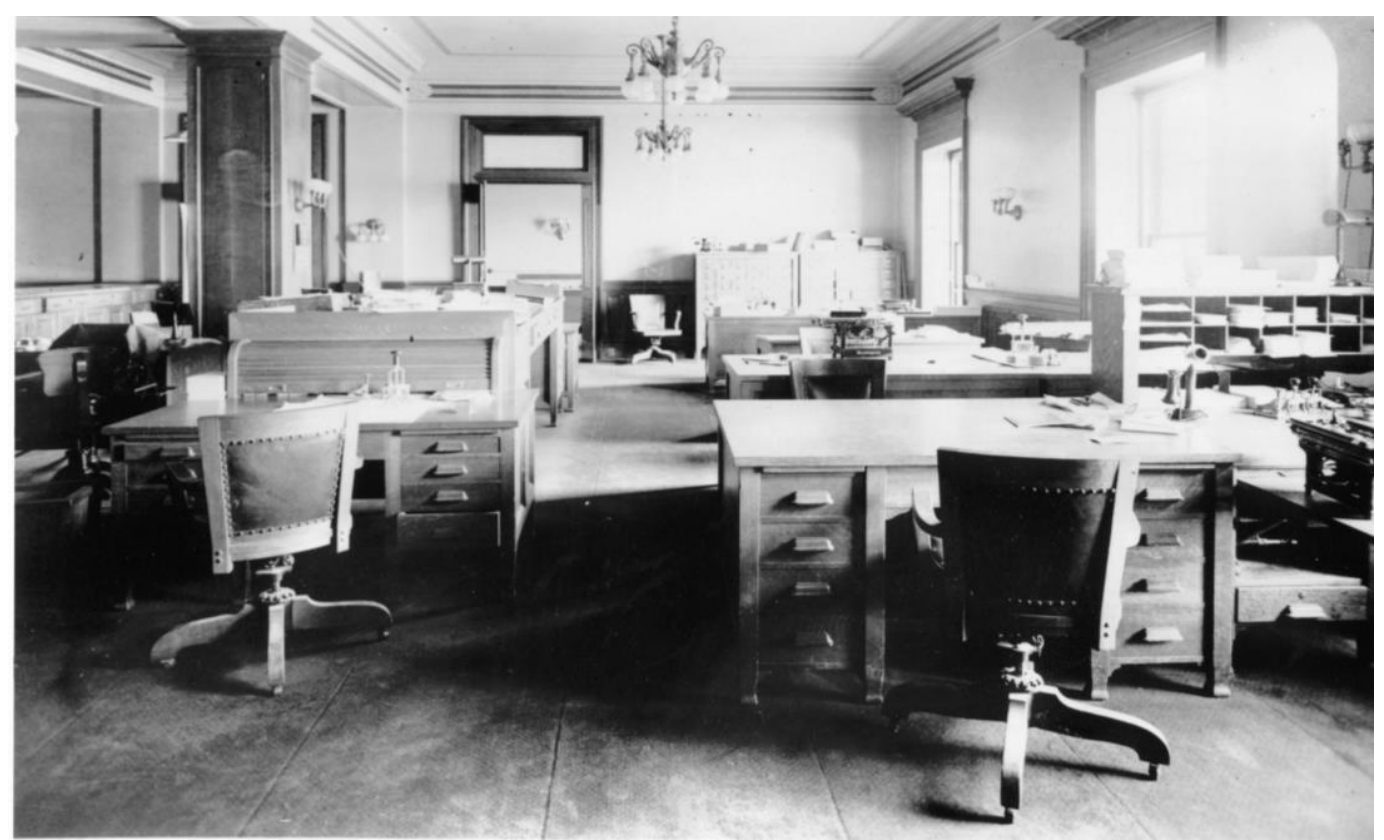

Figure 6. Clerks and Business Office, Wisconsin State Capitol, ca. 1917

Source: Photo Courtesy of Wisconsin Historical Society, WHi (x3) 50216.

Oak, a common American material, was the specified wood type. Cement floors were specified with Wilton carpeting that was either plain, or with small geometric patterns. Plastered walls were simply painted in either two or three hues, depending on spatial location (floor level). Ground floor offices 
exhibited a total of three paint hues per room, with the dado, wall field, and ceiling each having a single hue. Third floor business offices in the East Wing had only two hues per room, with no stripes or patterns. All ground floor and attic offices exhibited the simplest sconces and ceiling fixtures. ${ }^{62}$ Sconces had smooth brass arms, with translucent glass shades, and no applied ornament. Ceiling fixtures were simple pendant fixtures with exposed bulbs. Similarly, low level business offices in the Kentucky and Utah State capitols evinced their utilitarian function through their contemporary styles. A circa 1911 photograph of the Department of Education's general business office shows that the overall aesthetic is one of simplicity, and one influenced by modern reform movements (Figure 7).

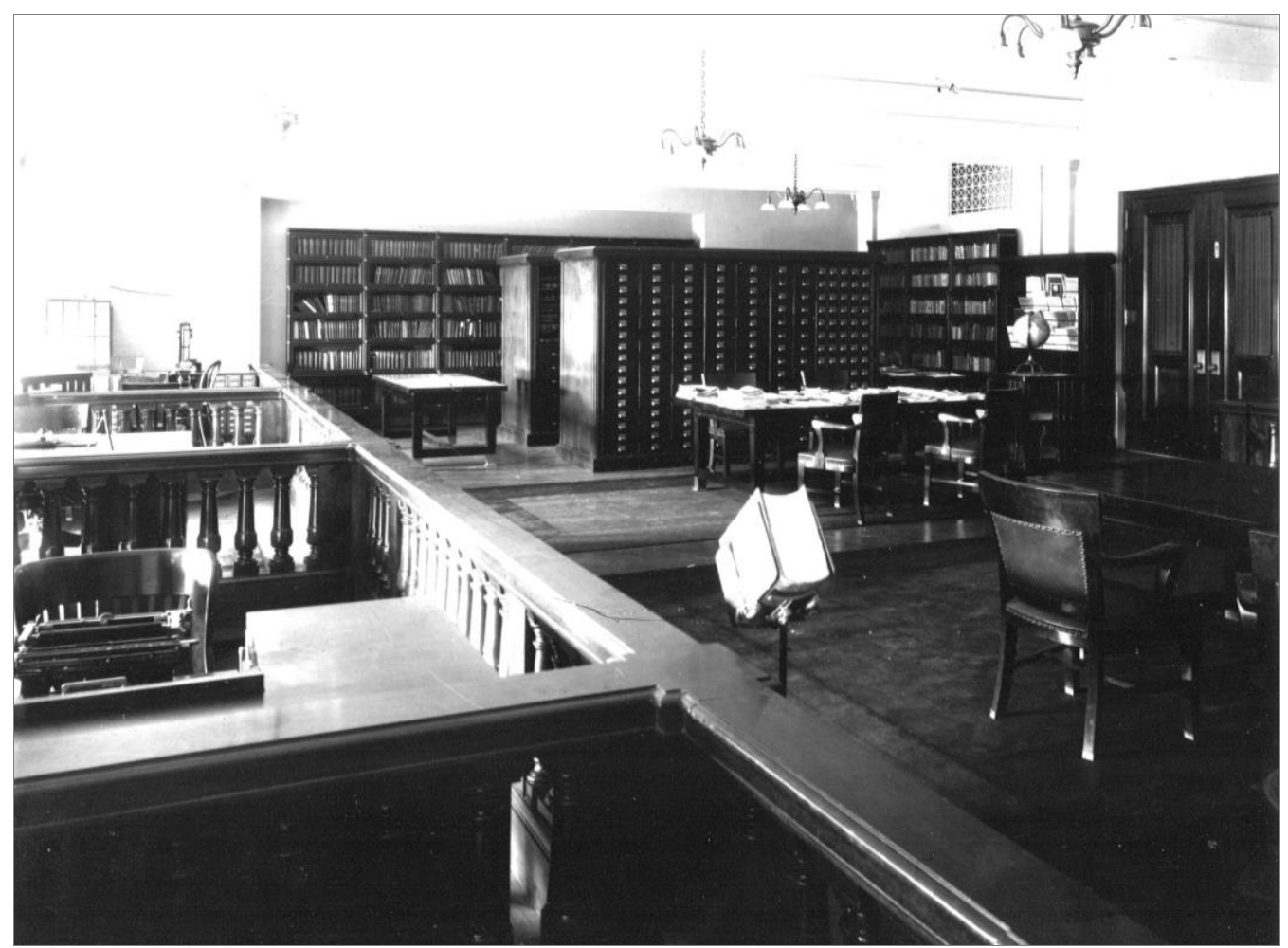

Figure 7. Department of Education Business Office, Kentucky Capitol, ca. 1910. Kentucky State Capitol Digital Collections

Source: Photo Courtesy of Kentucky Historical Society, 1987ph5.K122.2g.

George Lewis's 1910 Custodian's report intimates a commonality to the business offices of the ground floor, indicating they were the same style, and largely finished in oak. ${ }^{63}$ The floor in the office exhibits plain area rugs with a wide single border that is mitered. The walls and ceiling are simply painted in a light hue, and have no visible decorative finish patterns. Lighting consists of plain six-arm brass chandeliers with opaque glass globes. Consistent with the

62. George B. Post \& Sons, Wisconsin State Capitol, Schedule and Electric Fixture Drawing, 518-1654 (Capitol Commission Files, Wisconsin Historical Society, 1910). 1910).

63. Geo A. Lewis Custodian, Kentucky's New State Capitol (Frankfort: State of Kentucky, 
modern aesthetic of the European and American Arts \& Crafts Movements, furniture at this level had straight flat planes, an absence of historic ornament, and an emphasis on function over ornament.

Between the lowest level and highest levels of the democratic governmental hierarchy, caractére expression varied incrementally through styles, forms, materials, and construction. Visible variations reflected a continuum that gradually transitioned across each level of finish (decorative paint, furniture, lighting, and so forth), beginning with simple modern expressions and culminating in complex historic-inspired displays. At the apex resided the monumental and egalitarian chambers of the three branches of Government: executive, legislative, and judicial, each drawing on monumental and noble Italian Renaissance precedents, but varied by room type.

Important to consider, American semiotics were created and entwined within the French academic framework, rendering a European art historical form and style language intelligible and germane to the American public. For example, the principal ceiling mural of the Executive Chamber in the Wisconsin capitol enmeshes stripes of an American flag and words of the country's Declaration of Independence with classical iconography (Figure 8).

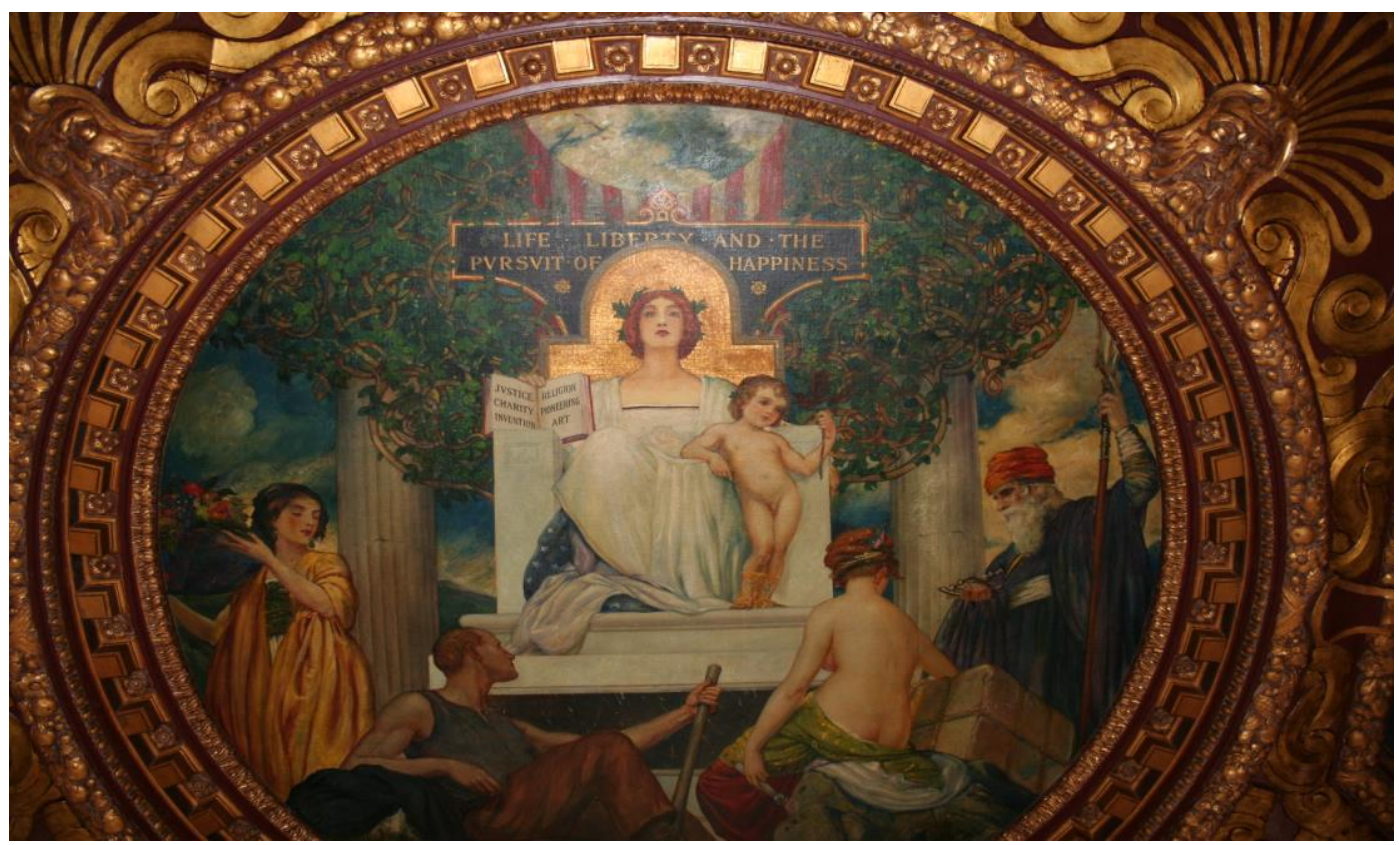

Figure 8. American Symbolism in Executive Chamber Ceiling Mural Wisconsin State Capitol, 1917

Source: Author.

Similarly, gilded balustrades of the Utah State Capitol's premiere hall, discreetly intersperse beehive motifs, a state symbol, amidst classical rinceaux (Figure 9). This process is ubiquitous across finishes in each capitol examined. 


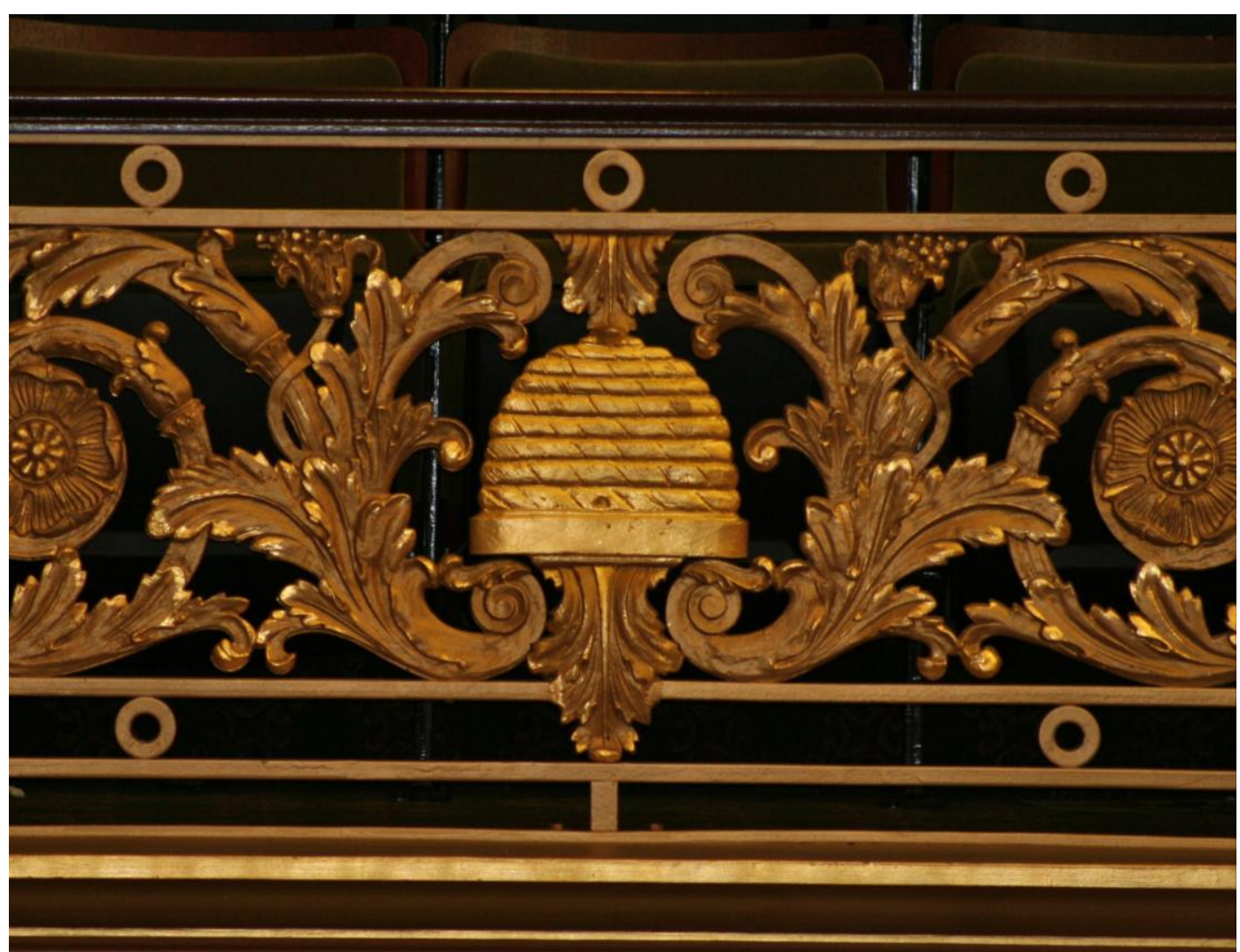

Figure 9. Beehive (State Symbol), Utah Capitol

Source: Author.

To summarize, for American Beaux-Arts architects, communicating supereminent caractère types in American capitols involved transmutation of purpose, value, iconography, and meaning of the French academic architectural hierarchy of buildings and interior programs, and its methodical expressions of architectural caractère. As a result, general and type caractère in American Beaux-Arts capitols, visually conveys the functions and rank of American democratic infrastructures, and imparts their social importance through the hierarchical and artistic form of language of the French Académie, discreetly entwined with American symbolism at every level. The hierarchy of interior spaces and rooms reflects Neoplatonic philosophy, in that rooms are ranked by their function and degree of utilitarian and ceremonial importance. It also reflects Aristotelian philosophy by visually communicating variations in rank through particular styles, forms, materials, construction and so forth. As evinced, utilitarian levels declared their practical value through modern forms and common materials, while ceremonial levels signified importance through revered historic forms and noble materials. The research corroborates Egbert findings that general and type characters were essential to express in the Beaux-Arts tradition during the nineteenth and early twentieth centuries. It demonstrates further that specific caractère manifested when the French academic design approach transposed in America. It was a means for architects 
to engage the intellect and emotions of American viewers, and render a European architectural form and style language amenable to them.

\section{Conclusions}

The paper analyzed the theoretical precepts that guided the French academic architectural tradition's varieties and meanings of exterior and interior caractère, and the typologies that they reflect and transpose. The study elucidates how architectural caractère developed to comprise the visual, physical, and communicative elements of each building, including its forms, styles, materials, art, iconography, decorative finishes, furnishings, construction, and so forth. Together, exterior and interior caractère types embody architectural history, social thought, contemporary purpose, aesthetic theory, and human innovation. As illuminated, precise deciphering of caractère's distinguishing features and semiotics in Beaux-Arts design is essential to interpret the didactic thought and precepts that guided a designer's decisions and the broader meanings of his or her material designs.

The analysis of the theoretical development and evolving connotations of architectural caractère in the French academic tradition reveals a foundation to understand and interpret the Académie's dominant pedagogic theories and principles, and their innovative translations abroad. To signify preeminent architectural caractère types, it is clear that the French Académie taught architects to organize and rank exterior and interior elements by their functions and corresponding social values, and to visually state stature and purpose through prescribed means including styles, forms, materials, construction, and so on. When the Beaux-Arts approach was interpreted outside of France, architects transmuted it by amalgamating cultural symbolism of the respective state to make it germane to that culture.

The study has pragmatic applications in academia and in contemporary practice. The scholarship reveals the principal tenets of an evolving academic architectural tradition that held appeal for over two millennia. The information facilitates sagacious discernment of intended semiotics in historic preservation practice and provides a theoretical basis for contemporary Neo Beaux-Arts Classicism. Importantly, it disseminates new knowledge on Beaux-Arts architectural theory from an interiors perspective, and expands prior scholarship on caractère qualities in American Beaux-Arts architectural tradition.

\section{Bibliography}

Blondel, Jacques-François. "Cours d'architecture" [Architecture Courses.] In Book of Architecture, 1771-1777, vol. 1. By Caroline van Eck. Translated by David Britt. Burlington, VT: Ashgate, 2002, 401.

Boffrand, Germain. Book of Architecture: Containing the General Principles of the Art and the Plans, Elevations, and Sections of Some of the Edifices Built in 
France and in Foreign Countries. Edited and Introduced by Caroline van Eck. Translated by David Britt. Burlington, VT: Ashgate, 2002, 1667-1754.

Cass Gilbert Collection (PR 21). New York: New York Historical Society, 1879-1934.

Cavelier, Guillaume. Livre d'Architecture (Paris: 1745).

Egbert, Donald Drew. The Beaux-Arts Tradition in French Architecture. Edited by David Van Zanten. Princeton, NJ: Princeton University Press, 1980.

Kentucky State Capitol Papers. Frankfort, KY: Division of Historic Properties.

Lewis, Geo A. Kentucky's New State Capitol. Frankfort, KY: State of Kentucky, 1910.

McKim, Mead and White Architectural Records Collection. Circa 1875 - 1950, bulk 1890-1930 (PR 42). New York: New York Historical Society.

Mostyn, Barbara. "The Content Analysis of Qualitative Research Data: A Dynamic Approach." In The Research Interview: Uses and Approaches. Edited by Michael Brenner, Jennifer Brown and David Canter. London: Academic Press, 1985.

Panofsky, Erwin. Meaning in the Visual Arts A59. Garden City, NJ: Doubleday Anchor Books, 1955.

Pollio, Marcus Vitruvius. Ten Books of Architecture. Translated by Morris Morgan. New York: Dover, 1960.

Post, George B. and Sons Architectural Records Collection. New York: New York Historical Society Library.

Post, George B. Architects at Dinner. New York Times, February 14, 1895.

Post, George B. to Geo. H. D. Johnson. Series 833 Correspondence. Madison: Wisconsin Capitol Commission Files, Wisconsin Historical Society, 1909.

Post, George Post \& Sons, Wisconsin State Capitol, Schedule and Electric Fixture Drawing. Madison: Capitol Commission Files. Wisconsin Historical Society, 1910, 518-1654.

Prown, Jules David. "Mind in Matter: An Introduction to Material Culture Theory and Method." Winterthur Portfolio 17, no. 1 (1982): 1-19.

Quatremère de Quincy, Antoine-Chrysostome. "Le Dictionnaire historique d'architecture, 1832" [The Historical Dictionary of Architecture, 1832.] In The True, The Fictive and the Real: The Historical Dictionary of Architecture by Quatremère de Quincy (Part II). Translated by Samir Younés. London: Andreas Papdakis, 1999.

Utah Capitol Commission Files. Salt Lake City: Utah State Archives.

Van Eck, Caroline. Book of Architecture: Containing the General Principles of the Art and the Plans, Elevations, and Sections of Some of the Edifices Built in France and in Foreign Countries. By Germain Boffrand. Burlington, VT: Ashgate, 2002.

Wisconsin Historical Images Collection. Madison: Wisconsin Historical Society.

Younés, Samir. The True, The Fictive and the Real: The Historical Dictionary of Architecture of Quatremère de Quincy (Part I Introductory Essays). London: Andreas Papadakis, 1999. 
